\title{
Seroepidemiological survey for leptospirosis in equines from semiarid region of Paraíba state, Northeastern Brazil
}

\section{Inquérito soroepidemiológico para leptospirose em equídeos no semiárido da Paraíba, Nordeste do Brasil}

\author{
Davidianne de Andrade Morais ${ }^{1}$; Diego Figueiredo da Costa ${ }^{1}$; Bruno Cesar Nunes ${ }^{1}$; \\ Carolina de Sousa Américo Batista Santos²; Clebert José Alves²; \\ Sérgio Santos de Azevedo ${ }^{2 *}$
}

\begin{abstract}
The aim of this survey was to determine epidemiological indicators for leptospirosis in equids from Paraíba state, Northeastern Brazil. A total of 138 equids were sampled from 58 rural properties, and for the diagnosis of leptospirosis it was used the Microscopic Agglutination Test (MAT) with 22 serovars as antigens. A seropositivity found was $40.6 \%(56 / 138)$. The reactive serogroups were Australis (43\%), Sejroe (16.3\%), Icterohaemorrhagiae (14.3\%), Grippotyphosa (10.2\%), Canicola (6.1\%), Tarassovi (4.1\%), Pomona (2\%), Ballum (2\%) and Hebdomadis (2\%). Animals over 36 months of age presented higher chance of get seropositive (odds ratio $=3.04 ; 95 \% \mathrm{CI}=1.23-7.56 ; P=0.016$ ). The results obtained in the present work point to the high occurrence of seropositive equids for Leptospira sp. in the semiarid of Paraíba, Northeastern Brazil. As it is the first report of seropositive equidae in Paraíba, other surveys should be conducted in the region aiming to isolate and identify the agent for the determination of the current infection in the animals.
\end{abstract}

Key words: Equids. Leptospirosis. Semiarid. Serogroups.

\section{Resumo}

O objetivo deste trabalho foi determinar indicadores epidemiológicos da leptospirose em equídeos do estado da Paraíba, Nordeste do Brasil. Foram amostrados 138 equídeos provenientes de 58 propriedades rurais, e para o diagnóstico da leptospirose foi utilizado o teste de Soroaglutinação Microscópica (SAM), utilizando uma bateria com 22 sorovares como antígenos. A sororreatividade encontrada foi de $40,6 \%$ (56/138). Os sorogrupos reatores foram Australis (43\%), Sejroe (16,3\%), Icterohaemorrhagiae (14,3\%), Grippotyphosa (10,2\%), Canicola (6,1\%), Tarassovi (4,1\%), Pomona (2\%), Ballum (2\%) e Hebdomadis (2\%). Animais com idade acima de 36 meses apresentaram maior chance de serem sororreativos (odds ratio $=3,04 ;$ IC $95 \%=1,23-7,56 ; P=0,016$ ). Os resultados obtidos no presente trabalho apontam para a elevada ocorrência de equídeos sororreagentes para Leptospira sp. no semiárido paraibano, Nordeste do Brasil. Sendo este o primeiro relato de equídeos sororreagentes na Paraíba, outros estudos devem ser conduzidos na região com o objetivo de isolar e identificar o agente para a determinação da infecção corrente nos animais.

Palavras-chave: Equídeos. Leptospirose. Semiárido. Sorogrupos.

\footnotetext{
1 Discentes, Curso de Doutorado, Programa de Pós-Graduação em Medicina Veterinária, Universidade Federal de Campina Grande, UFCG, Patos, PB, Brasil. E-mail: davidianneandrademorais@gmail.com; diegoveter@hotmail.com; bruno.cnunes@ hotmail.com

2 Profs., Programa de Pós-Graduação em Medicina Veterinária, UFCG, Patos, PB, Brasil. E-mail: carolamerico@yahoo.com.br; clebertja@uol.com.br; sergio@vps.fmvz.usp.br

* Autor for correspondence
} 
Horse farming generates millions of Brazilian Reais (BRL) every year and the market value of some of these animals is considered to be of a high zootechnical level. Besides having a high economic value, the horses also have a vital role to play in agribusiness (CASELANI et al, 2001). Leptospirosis is one of the diseases that has been detrimental to horse farming and public health; however, only a few studies have been carried out on horses in Brazil. Leptospirosis is caused by bacteria belonging to the genus of Leptospira and is an important zoonotic disease which is broad-based with significant impact on the economy and public health. It affects several diverse groups of mammals, including horses which are considered important hosts, due to their involvement with humans.

In horses, leptospirosis may occur either in the acute or chronic form; however, both forms can lead to disability and compromise the athletic performance of the affected steeds (HAMOND et al, 2012). The most common clinical symptoms include placentitis and spontaneous abortions, acute kidney failure, regular bouts of blood in the urine (hematuria), and inflammation of the eye (ophthalmia), which is considered the most significant cause of blindness among equines (ARTIUSHIN et al., 2012). A definite diagnosis of leptospirosis is possible through laboratory techniques, such as bacterial isolation; however, most cases are diagnosed serologically, mainly due to the difficulty associated with the isolation of the pathogenic leptospires (LEVETT, 2001). The World Organization for Animal Health (OIE) has designated Microscopic Agglutination Test (MAT) as the international reference benchmark for detecting leptospiral antibodies (OIE, 2014).

Data on the prevalence of leptospirosis in horses in Paraíba has not been adequately published. This study aimed to establish the frequency of and risk factors associated with leptospirosis in horses from rural farms in the semiarid region of the state of Paraíba, Northeast Brazil.
We considered horses from rural properties in the municipality of Bonito de Santa Fé, which lies within the mesoregion of the sertão (semiarid backlands) in Paraíba. In this region, livestock farming is one of the most important activities, especially the raising of horses; according to the report of Paraíba State Department for Development of Agribusiness and Fisheries (SEDAP-PB), there are 177 horse-rearing properties in the municipality. To calculate the size of the sample of properties, the formula for simple random sampling (THRUSFIELD, 2007), with an expected prevalence of 0.95 (HASHIMOTO et al., 2010) and a sampling error of 0.05 was used; a minimum sample size of 52 rural properties was calculated. A total of 138 horses ( 87 horses, 28 donkeys, and 23 mules) of different breeds, aptitudes, ages, and both sexes, from 58 different rural properties were included, of which, most were raised with other species, mainly cattle.

The owners of the animals were asked to complete an epidemiological questionnaire, in order to obtain information about the conditions and husbandry practices considered as risk factors for infection with Leptospira sp. The variables and their respective categories were as follows: type of rearing (extensive, semi-intensive, intensive), purpose (reproduction, draft, burden, sports, leisure), origin of the animals (from the property, from another property in the region, from another property in another region), participation in shows and auctions (no, yes), contact with other animals (no, yes), presence of other species on the property (cattle, pigs, goats or sheep, poultry, cats, dogs), occurrence of any wild animals on the property (no, yes), occurrence of uveitis in equines (no, yes), process for placentas / abortions among cattle (nothing done, buried or burnt, food for dogs), veterinary assistance on the property (no, yes), trained employees (no, yes), how long has the farm raised horses (less than 1 year, between 1 and 3 years, between 3 and 5 years, over 5 years), the main breed-type within the drove (thoroughbred, 
mixed-breed), are animals purchased (no, yes), where/from whom were the animals purchased (exhibition, auction or fair, shopkeepers, other properties), feeding on native pastures (no, yes), presence of irrigated land on the property (no, yes), access to water (water fountains, waterways, rivers, lakes, streams, water catchment areas), natural mounting (no, yes), controlled mounting (no, yes), artificial insemination (no, yes), common use of stud or semen between different properties (no, yes), occurrence of reproductive problems (no, yes), use of a large pasture area (no, yes), pasture with flooded areas (no, yes), periurban proximity (no, yes), leasing of pasture areas (no, yes), use of shared grazing land (no, yes), native pastures (no, yes), road access (no, yes), presence of rodents (no, yes), plan for rodent control (no, yes), burial or cremation of dead animals (no, yes), hygiene and asepsis of the premises (no, yes), isolation of dead animals (no, yes), picket for giving birth (no, yes), use of disposable syringes and needles (no, yes), performance of tests at the time of purchasing animals (no, yes), sex (male, female), pregnant (yes, no), species (horse, mule, donkey), breed (purebred, mixed breed), and age (up to 36 months, over 36 months).

The properties were visited between December 2014 and January 2015, and $8 \mathrm{~mL}$ of blood was collected from each animal through puncture of the jugular vein with a disposable $25 \times 0.8-\mathrm{mm}$ needle, after prior asepsis of the site with iodized ethyl alcohol. The collected material was placed in sterile test tubes, subjected to desorption, and stored in microtubes at $-20{ }^{\circ} \mathrm{C}$ until the serological tests were performed.

For serological diagnosis of leptospirosis, the Microscopic Agglutination Test (MAT; OIE, 2014) was used with 22 different antigens of Leptospira interrogans of the following serogroups supplied via Veterinary Bacteriology Laboratory of the Fluminense Federal University (UFF) from the Pasteur Institute, France: Australis (Australis and Bratislava serovars), Bataviae,
Canicola, Grippotyphosa, Sejroe (Hardjoprajitno and Wolffi serovars), Pomona, Pyrogenes, Icterohaemorrhagiae (Icterohaemorrhagiae and Copenhageni serovars), Hebdomadis, and Butembo; Leptospira borgpeterseni: serogroups Autumnalis, Ballum (Castellonis serovar), Sejroe (Hardjobovis serovar), Javanica and Tarassovi; Leptospira santarosai: serogroups Guaricura and Shermani; Leptospira kirschneri: Cynopteri serogroup; and Leptospira noguchii: Panama serogroup. The sera were screened at a concentration of 1:100. For each sample, the most frequent serogroup was considered as that which showed the largest titer; animals who presented similar titers for more than one serogroup were excluded from subsequent analysis.

The data (independent variables) acquired from the epidemiological questionnaire were linked to the conditions of each animal (reagent or not reagent; dependent variable) with regard to Leptospira sp. infection. The analysis of risk factors was carried out in two separate phases: univariate analysis and multivariate analysis. In the univariate analysis, each independent variable was crossed with the dependent variable, and those which a $P$-value of $\leq 0.20$ in the chi-square test (ZAR, 1999) were submitted for multivariate analysis using multiple logistic regression (HOSMER; LEMESHOW, 2000). For all analyses, a 5\% level of significance was considered and SPSS for Windows, version 12.0. was used.

In the sample of 138 horses, 56 (56/138) were seropositive based on the MAT test for at least one serogroup, which showed a frequency of $40.6 \%$ at concentration range of $1: 100$ to $1: 400$. The results of seropositivity by species are as follows: in the equine group, 39 out of 87 (44.8\%), in the donkey group, 6 out of $28(21.4 \%)$, and in the mule group, 23 out of $11(47.8 \%)$ had anti-Leptospira antibodies. Out of the 58 properties selected, $36(62.1 \%)$ had at least one seropositive animal. Out of the 56 animals that tested positive, seven were positive for two or more serogroups with similar concentrations and were therefore excluded from the calculation of 
the most common serogroup. The most frequent serogroup was Australis (43\%), followed in order by Sejroe $(16.3 \%)$, Icterohaemorrhagiae $(14.3 \%)$ and Grippotyphosa (10.2\%) (Table 1).

Table 1. Serogroups of Leptospira sp. at a greater frequency and the respective concentrations in horses in the semiarid region of Paraíba, in Northeastern Brazil, between December 2014 and January 2015.

\begin{tabular}{lcccc}
\hline & \multicolumn{3}{c}{ Concentrations } \\
\cline { 2 - 5 } Serogroups & $1: 100$ & $1: 200$ & $1: 400$ & TOTAL (\%) \\
\hline Australis & 14 & 5 & 2 & $21(43)$ \\
Sejroe & - & 5 & 3 & $8(16.3)$ \\
Icterohaemorrhagiae & 5 & 2 & - & $7(14.3)$ \\
Grippotyphosa & 1 & 4 & - & $5(10.2)$ \\
Canicola & 1 & 2 & - & $3(6.1)$ \\
Tarassovi & - & 2 & - & $2(4.1)$ \\
Pomona & - & 1 & - & $1(2)$ \\
Ballum & - & 1 & - & $1(2)$ \\
Hebdomadis & - & 1 & - & $1(2)$ \\
TOTAL & 21 & 23 & 5 & $49(100)$ \\
\hline
\end{tabular}

Reports of Moraes et al. (2010) in Pará and Santos et al. (2012) in Rio de Janeiro have indicated that serovars of the Australis serogroup were most common among horses in those states. Australis serogroup may be present in horses without causing any clinical illness; horses are considered as important maintenance hosts and sources of infection (PINNA et al., 2008). Leptospirosis due to this serogroup is mainly associated with reproductive problems, which usually progress silently and is largely unperceived, thereby harming the reproductive efficiency of the brood (PINNA, 2008).

Most studies on leptospirosis in horses in Brazil, have reported a greater occurrence of seroreactivity for Icterohaemorrhagiae (SANTOS et al., 2016); in this study, the third largest frequency was assigned to this serogroup (14.3\%). The confirmation of positive reactions for Icterohaemorrhagiae strengthens the recommendation for careful consideration of properties with the practice of synanthropic rodent control (SANTOS et al, 2012). Moreover, this serogroup is closely linked to human leptospirosis and is occupational in nature through infection of veterinarians, livestock farmers, slaughterhouse butchers, sanitation workers, and other people who coexist with the carrier animals (HARTSKEERL et al., 2011). Infection spreads mainly through contact with urine, remains of placenta and fetuses, or water contaminated with bacteria (PAIXÃO et al., 2016), and therefore, is of possible public health significance.

In our study, the Sejroe serogroup was the second most common serogroup. This highlights the contact between horses and bovines, which are considered as the main carriers of the bacteria (COELHO et al, 2014). Its occurrence is common in bovine serological reactions conducted in Brazil, which indicates the possibility of losses due to the use of a shared pasture system; this can be explained by the fact that horses may pick up leptospirosis through contact with infected urine from cattle or other infected animals, from contaminated water and pasture land, or additionally, infection spread 
through genital excretions, particularly of bovines (LEVETT, 2001).

The occurrence of Grippotyphosa serogroup is linked to environmental contamination, as this group is harbored by wild animals (HAMOND et al, 2015) and it affects equines the first in an incidental manner. The serological reaction for this serogroup also stresses probable infection in horses through contact with wild animals, since the target region of this study had many environments with animal life and conditions that aid the survival and spread of the agent.

In the present study, the other serogroups were detected at lower frequencies: Canicola (6.1\%), Tarassovi (4.1\%), Pomona (2\%), Ballum (2\%), and Hebdomadis (2\%). The diversity of serogroups observed could be explained by the contact between horses and the other species at locations in which Leptospira sp. are in circulation, and by the susceptibility of horses to these bacteria.

The results of univariate analysis with the variables of closest association $(P \leq 0.20)$, and occurrence of seropositive animals is shown in Table 2. In multivariate analysis, age of over 36 months was a significant risk factor (Odds ratio $=3.04$; CI 95\% $=1.23-7.56 ; P=0.016)$, which indicates greater exposure to the agent with age of the animal. Santos et al. (2012) conducted a seroepidemiological study of leptospirosis in equines in Rio de Janeiro and reported greater seropositivity for Leptospira sp. in animals at a more advanced age. Levett (2001) reported that contact with leptospires normally occurs at an early age of the animal, while prevalence increases as the animal gets older.

Table 2. Results of univariate analysis of significant variables $(\mathrm{p} \leq 0.20)$ associated with positive seroreaction for Leptospira sp. in horses in the semiarid region of Paraíba, Northeastern Brazil, between December 2014 and January 2015.

\begin{tabular}{|c|c|c|c|c|}
\hline Variable & Category & $\begin{array}{l}\text { Total number } \\
\text { of animals }\end{array}$ & $\begin{array}{c}\text { No. of animals testing } \\
\text { positive }(\%)\end{array}$ & $P$ \\
\hline \multirow[t]{2}{*}{ Use of animals for traction } & No & 75 & $35(46.7)$ & \\
\hline & Yes & 63 & $21(33.3)$ & 0.157 \\
\hline \multirow[t]{2}{*}{ Use of animals for sport } & No & 45 & $14(31.1)$ & \\
\hline & Yes & 93 & $42(45.2)$ & 0.164 \\
\hline \multirow[t]{2}{*}{ Presence of pigs on the property } & No & 76 & $36(47.4)$ & \\
\hline & Yes & 62 & $20(32.3)$ & 0.104 \\
\hline \multirow[t]{2}{*}{ Prevailing breed } & Pure & 4 & $0(0.0)$ & \\
\hline & Mixed & 134 & $56(41.8)$ & 0.146 \\
\hline \multirow[t]{2}{*}{ Occurrence of sale of animals } & No & 17 & $11(64.7)$ & \\
\hline & Yes & 121 & $45(37.2)$ & 0.057 \\
\hline \multirow[t]{2}{*}{ Occurrence of stillbirth } & No & 108 & $48(44.4)$ & \\
\hline & Yes & 30 & $8(26.7)$ & $\begin{array}{l}0.123 \\
\text { continue }\end{array}$ \\
\hline
\end{tabular}


continuation

\begin{tabular}{ccccc} 
Presence of rodents & No & 25 & $14(56.0)$ & \\
& Yes & 113 & $42(37.2)$ & 0.131 \\
Cleansing of the premises & & & & \\
& No & 2 & $54(39.7)$ & 0.163 \\
Examinations at the time of purchasing animals & Yes & 136 & $13(29.5)$ & \\
& No & 44 & $43(45.7)$ & 0.105 \\
Species & Yes & 94 & $39(44.8)$ & \\
& Equine & 87 & $6(21.4)$ & 0.067 \\
& Asinine & 23 & & \\
Age of animals & Mule & 28 & $9(23.1)$ & \\
& & & $47(47.5)$ & 0.015 \\
\hline
\end{tabular}

The results obtained in the present study suggested a high frequency of seropositivity for Leptospira sp. in horses in the semiarid region of Paraíba, in Northeast Brazil, especially in those aged over 36 months. To the best of our knowledge, this is the first report on seropositive horses in the state of Paraíba; future studies including a larger sample from a greater geographical area in the region are needed to establish epidemiology of the infection, and further efforts should focus on isolation and identification of leptospires in horses, to identify the etiological agent for the current infection in these animals.

\section{Acknowledgements}

The authors thank the National Council for Scientific and Technological Development (CNPq) for the research productivity fellow and financial aid (Process number 302222/2016-2).

\section{References}

ARTIUSHIN, S. C.; TIMONEY, J. F.; BALASURIYA, U. B.; EROL, E.; SELLS, S. F. Real-time PCR for detection of Leptospira interrogans serovar Pomona type kennewicki in equine clinical specimens. Journal of Equine Veterinary Science, Wildomar, v. 32, n. 10, p. 53, 2012. DOI: $10.1016 /$ j.jevs.2012.08.117.

CASELANI, K.; OLIVEIRA, P. R.; FERRAUDO, A. S. Estudo soroepidemiológico de leptospirose em equinos utilizados para tração urbana. Revista do Instituto Adolfo Lutz, São Paulo, v. 71, n. 3, p. 582-587, 2012. DOI: 1506. indd. 582

COELHO, E. L. M.; CHAVES, N. P.; SÁ, J. C.; MELO, S. A., SILVA, A. L. A. Prevalência de leptospirose em fêmeas bovinas abatidas em frigoríficos no município de São Luís, MA. Revista Brasileira de Medicina Veterinária, Rio de Janeiro, v. 36, n. 2, p. 111-115, 2014. DOI: 10.3821/690116-05RBMV022.

HAMOND, C.; MARTINS, G.; LILENBAUM, W. Subclinical leptospirosis may impair athletic performance in racing horses. Tropical Animal Health and Production, Edinburgh, v. 44,n. 8, p. 1927-1930, 2012. DOI: 10.1007/ s11250-012-0158-5.

HAMOND， C.; PINNA， M. H.;MARTINS， G.; MEDEIROS, M. A.; LILENBAUM, W. Infection by Leptospira spp. in Cattle in a Tropical Region, Rio de Janeiro, Brazil. The American Journal of Tropical Medicine and Hygiene, Cleveland, v. 92, n. 1, p. 210-210, 2015. DOI: 10.4269/ajtmh.14-0519.

HARTSKEERL, R. A.; COLLARES-PEREIRA, M.; ELLIS, W. A. Emergence, control and re-emerging leptospirosis: dynamics of infection in the changing world. Clinical Microbiology and 
Infection, New York, v. 17, n. 4, p. 494-501, 2011. DOI: 10.1111 / j.1469-0691.2011.03474.x.

HASHIMOTO, V. Y.; GARCIA, J. L.; SPOHR, K. A. H.; SILVA, F. G.; ALVES, L. A.; FREITAS, J. C. Prevalência de anticorpos contra Leptospira spp. em bovinos, caninos, equinos, ovinos e suínos do município de Jaguapitã, estado do Paraná, Brasil. Arquivos do Instituto Biológico, São Paulo, v. 77, n. 3, p. 521-524, 2010.

HOSMER, D. W.; LEMESHOW, S. Applied logistic regression. New York: John Wiley and Sons, 2000. 375 p.

LEVETT, P. N. Leptospirosis. Clinical Microbiology Reviews, Washington, v. 14, n. 2, p. 296-326, 2001. DOI: 1098-6618.

MORAES, C. C. G.; KURODA, R. B. S.; PINHO, A. P. V. B.; YWASAKI, F.; MENESES, A. M. C.; MARTINS, A. V. AMARAL JUNIOR, J. M.; DIAS, H. L. T.; VASCONCELLOS, S. A. Pesquisa de anticorpos para sorovares de Leptospira interrogans patogênicas em equídeos criados na ilha de Algodoal, Estado do Pará. Revista de Ciências Agrárias, Belém, v. 53, n. 2, p. 188194, 2010. DOI: 10.4322/rca.2011.027V

ORGANIZAÇÃO MUNDIAL DE SAÚDE ANIMAL - OIE. Leptospirosis, in: manual of diagnostic tests and vaccines for terrestrial animals. Paris: World Organization for Animal Health, 2014.
PAIXÃO, A. P.; SANTOS, P.; ALVES, L. M. C.; PEREIRA, H. M.; CARVALHO, H. F.; COSTA FILHO, V. M.; OLIVEIRA, E. A. A.; SOARES, D. M.; BESERRA P. A. Leptospira spp. em bovinos leiteiros do estado do Maranhão, Brasil: frequência, fatores de risco e mapeamento de rebanhos reagentes. Arquivos do Instituto Biológico, São Paulo, v. 83, n. 1, p. 1-12, 2016. DOI: 10.1590/1808-1657001022014.

PINNA, M. H.; VARGES, R.; LILENBAUM, W. Aplicação de um programa integrado de controle da leptospirose em equinos no Rio de Janeiro, Brasil. Revista Brasileira de Ciência Veterinária, Rio de Janeiro, v. 15, n. 2, p. 63-66, 2008. DOI: 10.4322/rbcv.2008.

SANTOS, R. F.; ASSIS, N. A.; SILVA, G. C. P.; MATHIAS, L. A. Agglutinins to Leptospira spp. in equines slaughtered in the southern region of Brazil. Semina: Ciências Agrárias, Londrina, v. 37, n. 2, p. 841852, 2016. DOI: 10.5433/1679-0359.

SANTOS, C. S.; GUEDES JUNIOR, D. S.; PEREIRA, R. C. G.; SANTOS, C. C. A.; CASTRO, V.; JESUS, V. L. $\mathrm{T}$. Inquérito sorológico da ocorrência de leptospirose em equídeos da microrregião de Itaguaí no estado do Rio de Janeiro-RJ. Revista Brasileira de Medicina Veterinária, Rio de Janeiro, v. 34, n. 2, p. 96-100, 2012.

THRUSFIELD, M. Veterinary epidemiology. London: Butterworths, 2007. 280 p.

ZAR, J. H. Biostatistical analysis. 4. ed. Upper Saddle River: Prentice Hall, 1999. 
